\title{
Biolistic transformation of wheat using the HMW-GS 1Dx5 gene without selectable markers
}

\author{
J.B. Qin, Y. Wang and C.Q. Zhu \\ Research Room of Molecular Biology \& Informatics, \\ Xinjiang Normal University, Urumqi, China \\ Corresponding authors: J.B. Qin / C.Q. Zhu \\ E-mail: jianbingqin@xjnu.edu.cn / zcqxj1966@163.com
}

Genet. Mol. Res. 13 (2): 4361-4371 (2014)

Received January 6, 2013

Accepted June 21, 2013

Published June 10, 2014

DOI http://dx.doi.org/10.4238/2014.June.10.3

\begin{abstract}
Genetic manipulation using linear DNA was applied to the common wheat variety Xindong No. 26 via particle bombardment with the aim to improve bread-making quality of flour. Initially, 2 biolistic parameters, helium pressure and target distance, were optimized using plasmid pAHC25. We transformed wheat immature embryo scutella with the linear $1 D x 5$ gene without selectable markers. The highest transient $\beta$-glucuronidase expression was obtained when scuttles were bombarded at 1100 psi with a 9-cm target distance. Using the optimized parameters, the transformation of the common wheat variety Xindong No. 26 was carried out using the linear $1 D x 5$. Three transgenic plants were identified from 1003 transgenic plants, yielding a transformation frequency of $0.4 \%$. A sodium dodecyl sulfate polyacrylamide gel electrophoresis analysis confirmed that the $1 D \times 5$ gene was expressed in $4 \mathrm{~T} 1$ seeds of the transgenic plants. These experiments indicate the possibility of obtaining marker-free transgenic wheat plants via particle bombardment using the minimal gene cassettes with the particle bombardment parameters.
\end{abstract}

Key words: Wheat; Particle bombardment; $\beta$-glucuronidase (GUS); Marker-free; Genetic transformation 


\section{INTRODUCTION}

Wheat seed protein is the main source of protein in the human diet. Glutens are the main components of dough and account for $46 \%$ of the total protein in the endosperm of the mature seed. Glutens consist of high molecular weight gluten subunits (HMW-GS) and low molecular weight gluten subunits that can be observed by sodium dodecyl sulfate polyacrylamide gel electrophoresis (SDS-PAGE). The HMW-GS was 90-147 kDa and contained 2 disulfide bonds, which have a direct decisive effect on the elasticity ( $\mathrm{Ng}$ and Bushuk, 1988) and the bread-baking quality (Shewry et al., 1989). The gene locus controlling HMW-GS is located on the long arm of the chromosomes (1A, 1B, and 1D) of the first-group common wheat (Triticum aestivum L.) (Bietz et al., 1975; Payne et al., 1987). Research shows that in different wheat cultivars, the number of subunits, types of allelic variation, and differences in expression levels of genes cause variation in the elasticity of the dough and the pasta manufacturing quality. Among the varieties, $1 A x 1,1 D x 5$, and $1 D y 10$ are considered to be high-quality gluten subunit genes (Shewry et al., 1992). Therefore, the wheat varieties that contain subunit genes and express them normally have broad prospects in production.

The investigative group cloned the $1 D x 5$ gene from xinchun 19 and L88-6 (Liu et al., 2011) in order to utilize the high-quality gluten subunit gene $1 D x 5$. The gene was transferred to common wheat, planted in a large area, and expected to improve the processing quality of the wheat. Selectable marker genes can facilitate obtaining transgenic plants instantly. However, the presence of these genes has a direct effect on the transgenic crop in the market and also narrows the beneficiary profile from growers to consumers, which could in turn have important implications for public acceptance (Yoder and Goldsbrouugh, 1994).

In addition, removing the selectable marker gene so as to minimize the potential safety problem of transgenic plants has great significance to the further utilization of transgenic plants. At present, the co-transformation method has been successfully employed for the removal of selectable marker genes from transgenic plants (Uzé et al., 1999; Alvarez et al., 2000; Fu et al., 2000; Yao et al., 2006; Liu et al., 2011).

Today, the particle bombardment method is widely used for wheat transformation, and many researchers have obtained illuminating results. However, the bombardment distance, bombardment pressure, amount of plasmid DNA, amount of gold particles, and chamber vacuum pressure greatly influence the wheat transformation efficiency. The acceleration pressure and target distance are 2 important factors that affect bombardment. Since the first transgenic wheat plants were obtained via bombardment particles (Vasil et al., 1992), the bombardment parameters have been optimized to control the DNA delivery by bombardment particles to wheat (Rasco-Gaunt et al., 1999; Chernobrovkina et al., 2007; Sarwan et al., 2010), but the results vary.

The objective of this study was to optimize the acceleration pressure and target using $\beta$-glucuronidase (GUS) gene transient expression experiments in the immature embryo scutella of Xindong No. 26 via bombardment particles. Using the optimized conditions, a linear $1 D x 5$ gene without a selectable marker gene was transformed into the immature embryo scutella of Xindong No. 26 via bombardment particle. These developments will be helpful for improving the processing quality of wheat and will lay a foundation for improving the processing quality of wheat using the HMW-GS gene. 


\section{MATERIAL AND METHODS}

\section{Plant material and culture conditions}

The winter wheat variety Xindong No. 26 from the Xinjiang region of China was chosen as the experimental material. Spikes were harvested 12 or 13 days after flowering. Immature seeds were surface-sterilized with $0.1 \%(\mathrm{v} / \mathrm{v}) \mathrm{HgCl}_{2}$ for $12 \mathrm{~min}$ and then rinsed 4 times with sterilized deionized water. Scutella from immature embryos were isolated. Immature embryos were placed on MSI medium, which contained MS basal medium, 1.5 $\mathrm{mg} / \mathrm{L}$ 2,4-dichlorophenoxyacetic acid (2,4-D), $0.5 \mathrm{mg} / \mathrm{L}$ dicamba, $3 \%$ sucrose, and $8 \mathrm{~g} / \mathrm{L}$ agar, $\mathrm{pH}$ 5.8. Cultures were incubated at $25^{\circ} \mathrm{C}$ in darkness for approximately $48 \mathrm{~h}$ before bombardment.

\section{Bacterial strains and plasmids}

The plasmid pAHC25 containing both the GUS and BAR genes was used to optimize the transient expression by the GUS assay. The linear $1 D x 5$ gene without selectable markers was used in transformation experiments.

\section{Bombardment parameters}

Bombardments were carried out with particle bombardment (PDS 1000/He, Bio$\mathrm{Rad}$ ) under a vacuum of 27 inches of $\mathrm{Hg}$. The standard transformation procedure is based on the method that was described previously and subsequently modified (Rasco-Gaunt et al., 1999; Sparks and Jones, 2004). The variables to be optimized included rupture disc pressures $(900,1100$, and $1350 \mathrm{psi})$ and the distance from the rupture disk to the macrocarrier (6 and $9 \mathrm{~cm})$.

\section{Histochemical GUS assay}

Sixteen hours after bombardment, explants were vacuum infiltrated for 10 min with 5-bromo-4-chloro-1H-indol-3yl- $\beta$-D-glucopyranosiduronic acid (X-gluc) buffer containing $1 \mathrm{mM}$ X-gluc, $100 \mathrm{mM}$ sodium phosphate buffer, $\mathrm{pH}$ 7.0, $0.5 \mathrm{mM}$ potassium ferricyanide, $0.5 \mathrm{mM}$ potassium ferrocyanide, and $0.1 \%$ Triton X-100 (v/v). Blue staining was assessed after incubation for $8 \mathrm{~h}$ at $37^{\circ} \mathrm{C}$.

\section{Biolistic transformation using optimized conditions}

Explants were subsequently bombarded under the optimized bombardment parameters of 1100 psi helium pressure and 9-cm target distance. In this study, the linear 1Dx5 gene was used for transformation. After bombardment, the callus was first incubated in high osmotic medium for $16 \mathrm{~h}$, and then it was incubated in induction medium (MSI) for 4 weeks in the dark at $25^{\circ} \mathrm{C}$ (Figure 1). The callus was cultured on the regeneration medium [containing R (Qin and He, 2001) medium; $1 \mathrm{mg} / \mathrm{L}$ Zeatin (ZT), $0.01 \mathrm{mg} / \mathrm{L} 2,4-\mathrm{D}, 30 \mathrm{~g} / \mathrm{L}$ maltose] for 4 weeks under light at $22^{\circ} \mathrm{C}$ with a medium change every 2 weeks (Figure 2). 


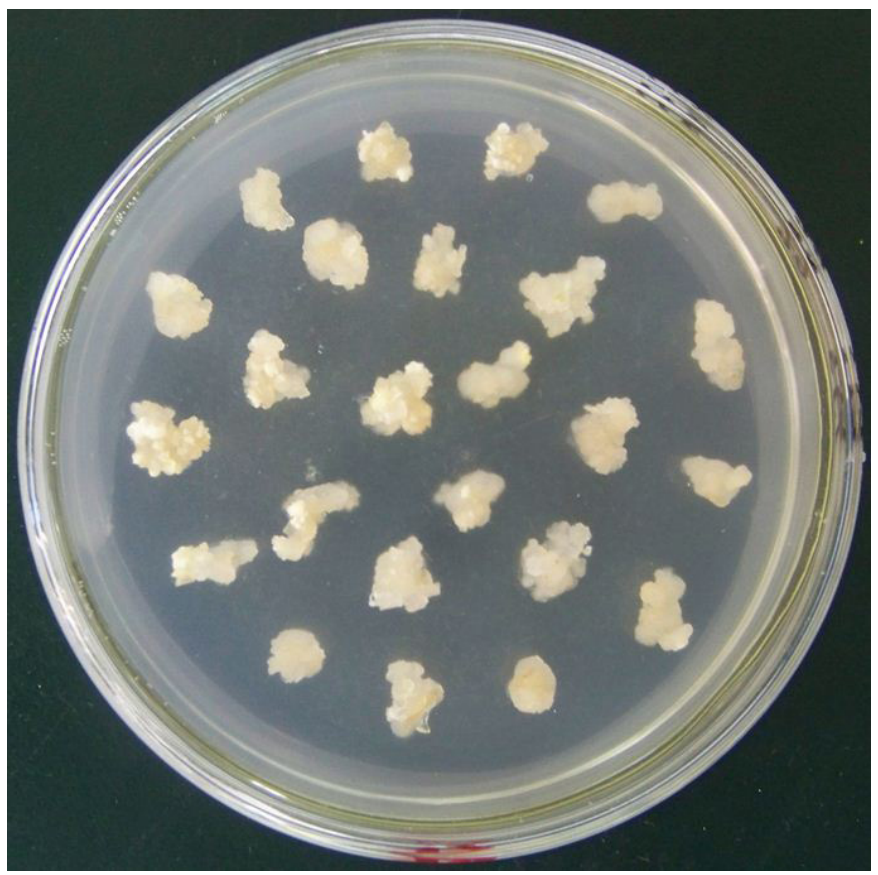

Figure 1. Callus vegetated on the induction medium for 4 weeks.

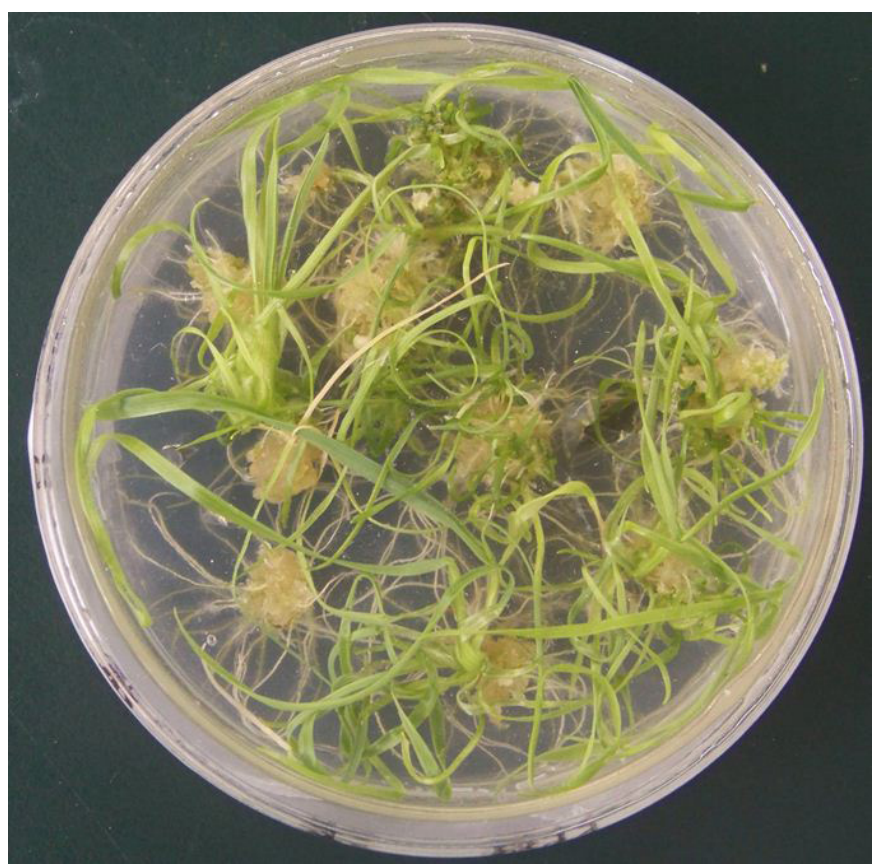

Figure 2. Plant regenerated on the differentiation medium for 4 weeks. 


\section{Polymerase chain reaction (PCR) selection of transgenic plants}

For all of the regenerated plantlets, total genomic DNA of $20 \mathrm{~T} 0$ progenies was isolated from leaf material and analyzed by PCR as a group. The primers that were to the $1 D x 5$ gene were F: 5'-AAAAGGTATTACCCAAGTGTAACTTGTCCG-3' and R: 5'-AATTGTCCTGGCTGCAGCTGCGA-3' at an annealing temperature of $66^{\circ} \mathrm{C}$, resulting in an expected amplified product of $343 \mathrm{bp}$ (1Dx5 gene-specific fragment) and $361 \mathrm{bp}(1 D \times 2$ gene-specific fragment).

\section{Expression analysis of transgenic wheat}

Protein extracts from T1 and subsequent generation endosperms were analyzed by SDS-PAGE for changes in HMW-GS content (Zhu et al., 2008). Total proteins were extracted from single-half grains.

\section{RESULTS}

\section{Effect of helium pressure}

Different helium pressures affect transient GUS expression in bombardment parameters. The acceleration pressure obviously determines the distribution in target tissues and depth of particle penetration. Acceleration pressures that are too high tend to damage the target tissues, whereas pressures that are too low to penetrate the tissue cell cause no transient expression (Yao et al., 2006). It was observed that 1100 psi helium pressure gave the highest $(0.96 \pm 0.05)$ transient GUS gene expression compared to $900 \mathrm{psi}(0.62 \pm 0.03)$ and $1350 \mathrm{psi}$ $(0.56 \pm 0.01)$ when scutella were bombarded with a 9 -cm target distance (Table 1).

Table 1. Effect of helium pressure (psi) on GUS expression $24 \mathrm{~h}$ after bombardment of wheat, at a 9-cm target distance.
\begin{tabular}{lcc}
\hline Helium pressure (psi) & Bombardment explants (No.) & Percentage of explant-expressed GUS \\
\hline 900 & 25 & $0.62 \pm 0.03^{\mathrm{b}}$ \\
1100 & 25 & $0.96 \pm 0.05^{\mathrm{a}}$ \\
1350 & 25 & $0.56 \pm 0.01^{\mathrm{b}}$ \\
\hline Means with the same letter are not significant at $\mathrm{P}=0.05$.
\end{tabular}

The low acceleration pressures (900 psi, $1100 \mathrm{psi})$ tend to result in larger areas that are covered by particles than the higher acceleration pressure (1350 psi) (Figure 3). At high pressure, a small area of the target tissues was very strongly targeted and thus likely to be damaged (Figure 3C).

\section{Effect of target distance}

The results showed differences between the 2 target distances, and the highest GUS expression (93\%) was observed when the 9-cm distance was used with 1100 psi helium pressure (Table 2). The number of explants with blue color was higher when the target distance was $9 \mathrm{~cm}$ (Figure 4). In contrast, the transient GUS expression (56\%) was low at the 6-cm 
target distance (Table 2). Therefore, in the subsequent experiments, a 9-cm target distance and 1100 psi helium pressure were used.
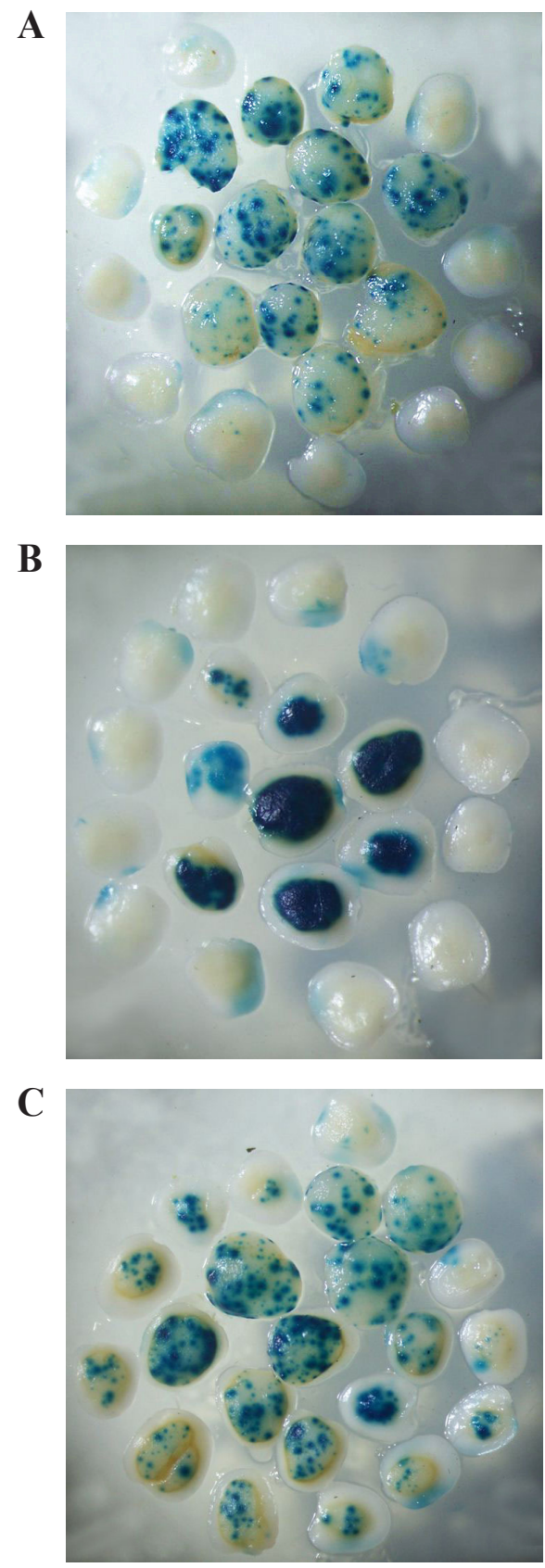

Figure 3. Comparison of transient GUS expression in wheat scutellum bombarded with 900 to 1350 psi at a 9-cm target distance. A. 900 psi. B. 1100 psi. C. 1350 psi. 
Table 2. Effect of different target distance on GUS expression in yellow watermelon cotyledons at 1100 psi helium pressure $24 \mathrm{~h}$ after bombardment.

\begin{tabular}{lcc}
\hline Target distance $(\mathrm{cm})$ & Bombardment explants (No.) & Percentage of explant-expressed GUS \\
\hline 6 & 25 & 0.56 \\
9 & 25 & 0.93 \\
\hline
\end{tabular}

$\mathbf{A}$

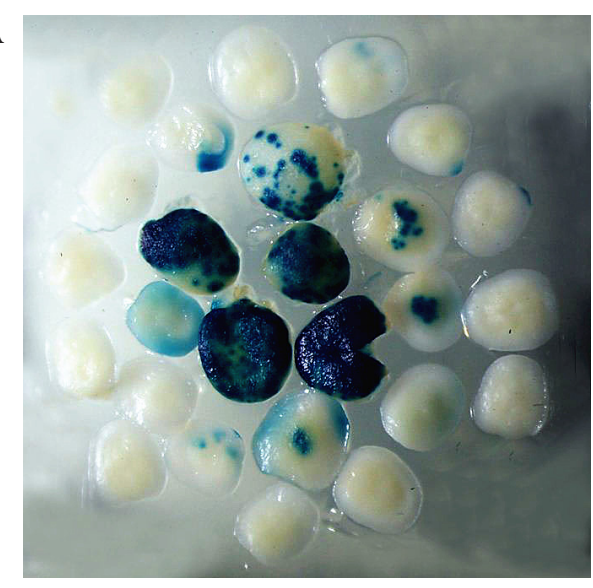

B

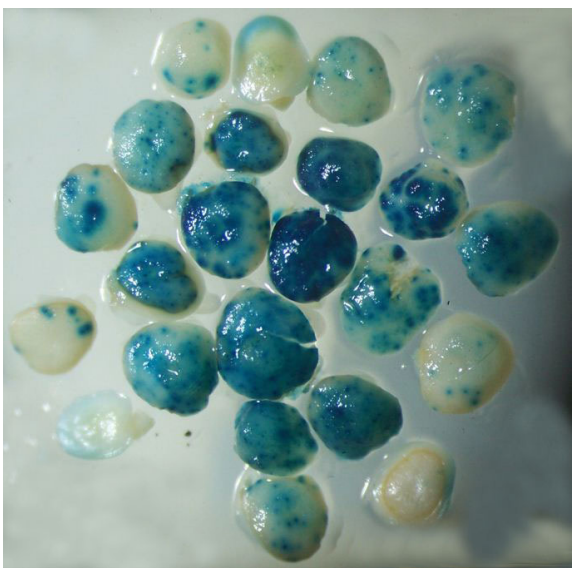

Figure 4. Comparison of transient GUS expression in wheat scutellum bombarded with 6 to $9 \mathrm{~cm}$ at 1100 psi helium pressure. A. $6 \mathrm{~cm}$. B. $9 \mathrm{~cm}$.

\section{Transgenic plant selection}

About 1000 immature embryo scutella were bombarded with the linear $1 D x 5$ gene via particle bombardment and were regenerated under non-selective conditions. All 1003 regenerated plantlets were screened for the presence of $1 D x 5$ gene sequences by PCR dichotomy analysis. A 343-bp product (1Dx5 gene-specific fragment) was amplified in the transgenic plants and the positive control. 
Total genomic DNA of each of $20 \mathrm{~T} 0$ progenies was isolated from leaf material and analyzed by PCR as a group. Three groups showed the expected 343-bp band size of the $1 D x 5$ gene and were taken as positive groups (Figure 5). The DNA of the control plant did not show any amplification of the 343-bp band. The DNA was extracted from each plantlet of the positive groups and analyzed to identify each positive plantlet. Four positive plants were identified (Figure 6). The transformation frequency was $0.4 \%$.

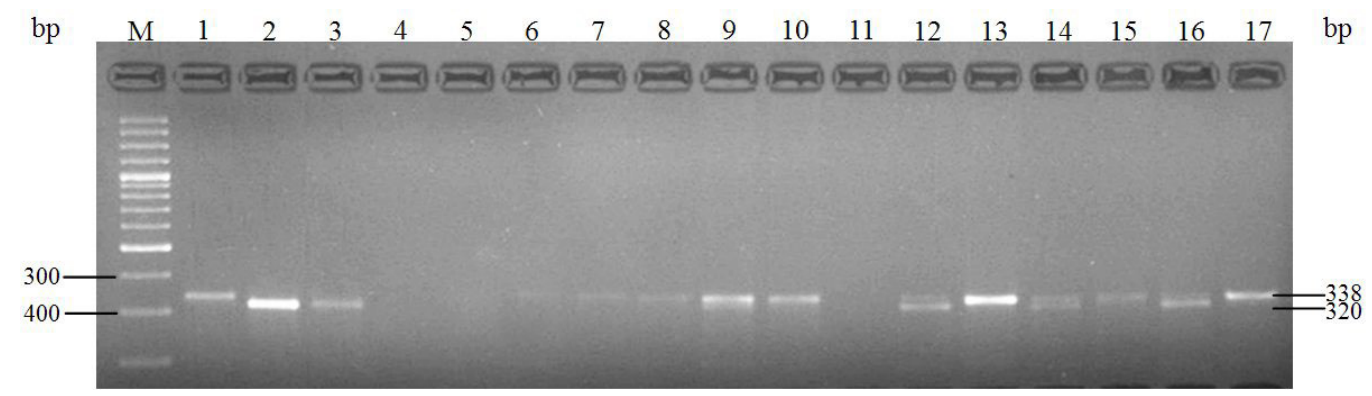

Figure 5. PCR analyses of 20 transgenic plants. Lane $M=$ marker; lane $1=$ Xindong No. 26 donor plants for the negative control; lanes 2 and $3=1 D \times 5$ for the positive control; lanes $4-17=$ different transgenic plants.

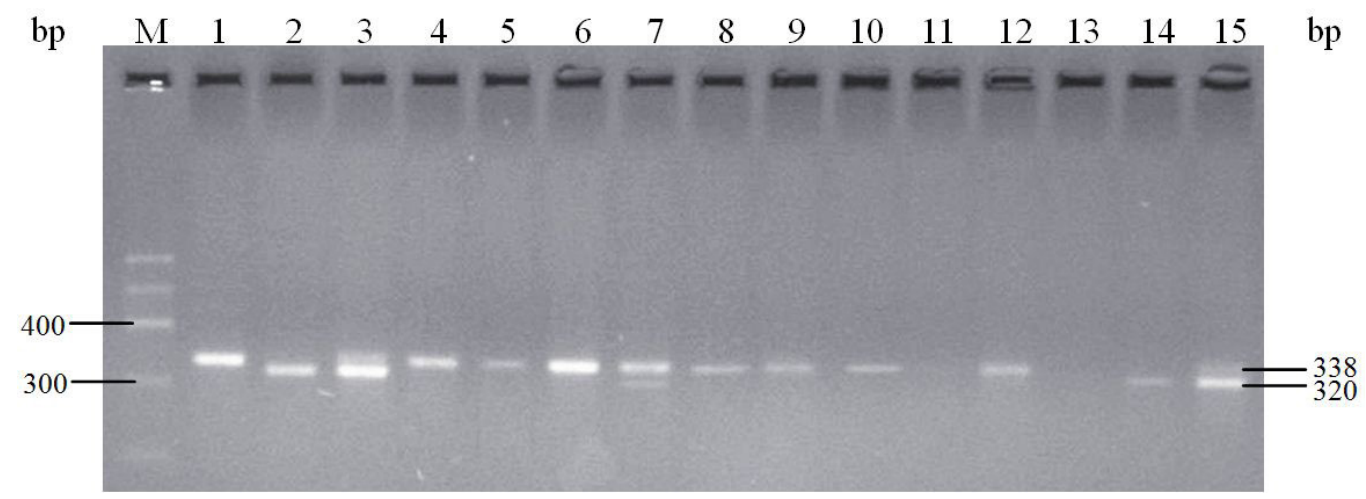

Figure 6. Selection of transgenic wheat plants with PCR. Lane $M=$ marker; lane $1=$ Xindong No. 26 donor plants for the negative control; lane $2=1 D \times 5$ for the positive control; lanes 3-15=different transgenic plants.

\section{Expression analysis of transgene HMW-GS $1 D x 5$}

The endosperm storage proteins were extracted from all $\mathrm{T} 1$ transgenic plants from half of the seed, and the other half contains mature embryos that were used for breeding. SDS-PAGE was used to determine if the HMW-GS gene was expressed in transformed plants, and 46 transgenic T1 seeds were identified. Figure 7 shows part of the SDS-PAGE analysis. Expression of $1 D x 5$ was observed in T1 seeds that were harvested from positive plants. 


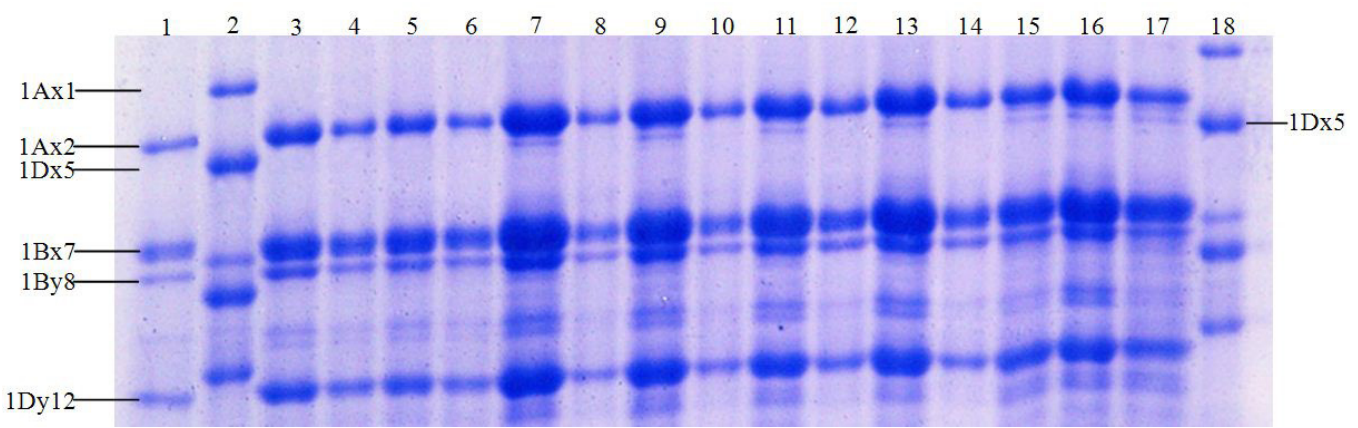

Figure 7. SDS-PAGE of total protein from partial T1 transgenic seeds. Lane $1=$ China Spring; lanes 2 and $18=$ L88-6 genotype for the positive control; lane 3 = Xindong No. 26 donor plants for the negative control; lanes 4-6, $8,10,12,14=$ different non-transgenic plants; lanes $7,9,11,13,15-17=$ different transgenic plants.

\section{DISCUSSION}

Particle bombardment has been widely exploited to produce tissues and plants that express traits with agronomic value, and it has had a major impact on basic plant science research and biotechnology (Taylor and Fauquet, 2002; Altpeter et al., 2005). The objective of this study was to establish an HMW-GS $1 D x 5$ transformation system and to use the biolistic transformation system with optimized conditions. The bombardment parameters of acceleration pressure and target distance were optimized.

One of the most important parameters to optimize for biolistic transformation is the target distance between the macrocarrier and the target tissue in the bombardment chamber. This directly affects the distance that the microcarriers travel to the target cells for penetration and gene transfer into plant genome (Sarwan et al., 2010; Swati et al., 2012). We found significantly higher transient GUS expression and transformation efficiency when immature embryo scutella were placed $9 \mathrm{~cm}$ away from the macrocarrier. The same distance was found to be significantly better than other distances in wheat (Swati et al., 2012). Contrary to this, previous investigations in wheat reported that a $6-\mathrm{cm}$ distance from the rupture disk to the macrocarrier was optimum compared to 9 and $12 \mathrm{~cm}$ (Yao et al., 2006). This difference in target distance might be related to bombardment of the tissue with the dispersion of gold. In addition, there are also concerns about the donor conditions.

The helium pressure had a significant effect on the microprojectile bombardment that mediated genetic transformation. There was no significant difference in GUS expression at pressures of 650-1100 psi, while the expression was significantly reduced at higher pressures (Rasco-Gaunt et al., 2001). We found that helium pressure of 1100 psi gave the highest transient GUS expression and transformation efficiency in wheat. The frequency of transient GUS expression decreased with increased or decreased helium pressure.

In this investigation, a linear gene expression cassette carrying $1 D x 5$ was transformed into wheat. The cassette was produced in such a way that no extra-vector sequences were introduced into transgenic wheat. This means that the cassette containing only a promoter, coding sequence, and a 3'-terminator was successfully induced into the genome and used for a transformation system of wheat (Uzé et al., 1999). Even though we can quickly obtain the transgenic plants with cassettes that carry only essential genetic elements, the efficiency of 
transformation was low in this study $(0.4 \%)$ compared with that in previous studies (1.4 and $1.5 \%$ ) (Rooke et al., 1999; Gadaleta et al., 2008). However, the frequency of transformation was significantly higher using a linear GUS/BAR gene than the whole plasmid (Uzé et al., 1999; Yao et al., 2006). The low transformation frequency might due to the absence of selective pressure, without which transformed cells tend to be disadvantageous in competition with non-transformed cells and consequently die more (Mullins et al., 1990).

In this study, transgenic wheat plants were generated using the linear $1 D x 5$ gene in the common wheat variety Xindong No. 26. The optimization of transformation parameters was helpful to improve the frequency of transformation.

\section{ACKNOWLEDGMENTS}

The authors thank the National Natural Science Foundation of China (\#30960044) and Western Light Joint Researcher Program (Transformation and Germplasm Enhancement of Wheat Quality Gene in Saline Tolerant Wheat Variety).

\section{REFERENCES}

Altpeter F, Baisakh N, Beachy R, Bock R, et al. (2005). Particle bombardment and the genetic enhancement of crops: myths and realities. Mol. Breed. 15: 305-327.

Alvarez ML, Guelman S and Halford NG (2000). Silencing of HMW glutenins in transgenic wheat expressing extra HMW subunits. Theor. Appl. Genet. 100: 319-327.

Bietz JA, Shepherd KW and Wall JS (1975). Single-kernel analysis of glutenin: Use in wheat genetics and breeding. Cereal Chem. 52: 513-532.

Chernobrovkina MA, Sidorov EA, Baranov IA, Kharchenko PN, et al. (2007). The effect of the parameters of biolistic transformation of spring barley (Hordeum vulgare L.) on the level of transient expression of GFP reporter gene. Izv. Akad. Nauk Ser. Biol. 6: 669-675.

Fu X, Duc LT, Fontana S, Bong BB, et al. (2000). Linear transgene constructs lacking vector backbone sequences generate low-copy-number transgenic plants with simple integration patterns. Transgenic Res. 9: 11-19.

Gadaleta A, Blechl AE, Nguyen S, Ventura M, et al. (2008). Stably expressed D-genome-derived HMW glutenin subunit genes transformed into different durum wheat genotypes change dough mixing properties. Mol. Breed. 22: 267-279.

Liu X, Jin W, Liu J, Zhao H, et al. (2011). Transformation of wheat with the HMW-GS 1Bx14 gene without markers. Genetika 47: 206-212.

Mullins MG, Tang FC and Facciotti D (1990). Agrobacterium mediated genetic transformation of grapevines: Transgenic plants of Vitis rupestris Scheele and buds of Vitus vinifera L. Nat. Biotechnol. 8: 1041-1045.

Ng KW and Bushuk W (1988). Statistical relationships between high molecular weight subunits of gluten and bread making quality of Canadian grown wheats. Cereal Chem. 65: 408-413.

Payne PI, Nightingale MA and Krattiger AF (1987). The relationship between HMW glutenin subunit composition and the bread-making quality of British-grown wheat varieties. J. Sci. Food Agr. 40: 51-65.

Qin JB and He GY (2001). Preliminary study on in vitro culture of different wheat genotypes and their explants. $J$. Huazhong Agr. Univ. 20: 522-527.

Rasco-Gaunt S, Riley A, Barcelo P and Lazzeri PA (1999). Analysis of particle bombardment parameters to optimize DNA delivery into wheat tissues. Plant Cell Rep. 19: 118-127.

Rasco-Gaunt S, Riley A, Cannell M, Barcelo P, et al. (2001). Procedures allowing the transformation of a range of European elite wheat (Triticum aestivum L.) varieties via particle bombardment. J. Exp. Bot. 52: 865-874.

Rooke L, Barro F, Tatham AS, Fido R, et al. (1999). Altered functional properties of tritordeum by transformation with HMW glutenin subunit genes. Theor. Appl. Genet. 99: 851-858.

Sarwan D, Kaye KC, Livia P and Mann J (2010). Optimization and transformation of Arundo donax L. using particle bombardment. Afr. J. Biotechnol. 9: 6460-6469.

Shewry PR, Halford NG and Tatham AS (1992). High molecular weight subunits of wheat glutenin. J. Cereal Sci. 15: 105-120. 
Shewry R, Halford NG and Tatham AS (1989). The high molecular weight subunits of wheat barley and rye: genetics, molecular biology, chemistry and role in wheat gluten structure and functionality. Oxford Survey Plant Mol. Cell Biol. 6: 163-219.

Sparks CA and Jones HD (2004). Transformation of Wheat by Biolistics. In: Transgenic Crops of the World Essential Protocols (Curtis IS, ed.). Kluwer Publishers, Dordrecht, 19-34.

Swati JC, Sumita K, Manju S, Aditi KC, et al. (2012). Optimization of factors influencing microprojectile bombardmentmediated genetic transformation of seed-derived callus and regeneration of transgenic plants in Eleusine coracana (L.) Gaertn. Plant Cell Tissue Organ Cult. 109: 401-410.

Taylor NJ and Fauquet CM (2002). Microparticle bombardment as a tool in plant science and agricultural biotechnology. DNA Cell Biol. 21: 963-977.

Uzé M, Potrykus I and Sautter C (1999). Single-stranded DNA in the genetic transformation of wheat (Triticum aestivum L.): transformation frequency and integration pattern. Theor. Appl. Genet. 99: 487-495.

Vasil V, Castillo AM, Fromm ME and Vasil IK (1992). Herbicide resistant fertile transgenic wheat plants obtained by microprojectile. Nat. Biotechnol. 10: 667-674.

Yao Q, Cong L, Chang JL, Li LX, et al. (2006). Low copy number gene transfer and stable expression in a commercial wheat cultivar via particle bombardment. J. Exp. Bot. 57: 3737-3746.

Yoder JI and Goldsbrouugh AP (1994). Transformation system for generating marker-free transgenic plants. Nat. Biotechnol. 12: 263-267.

Zhu CQ, Li YH and Qin JB (2008). Analysis of high-molecular-weight glutenin subunit composition from Xinjiang wheat cultivars. J. Huazhong Normal Univ. 42: 431-434. 